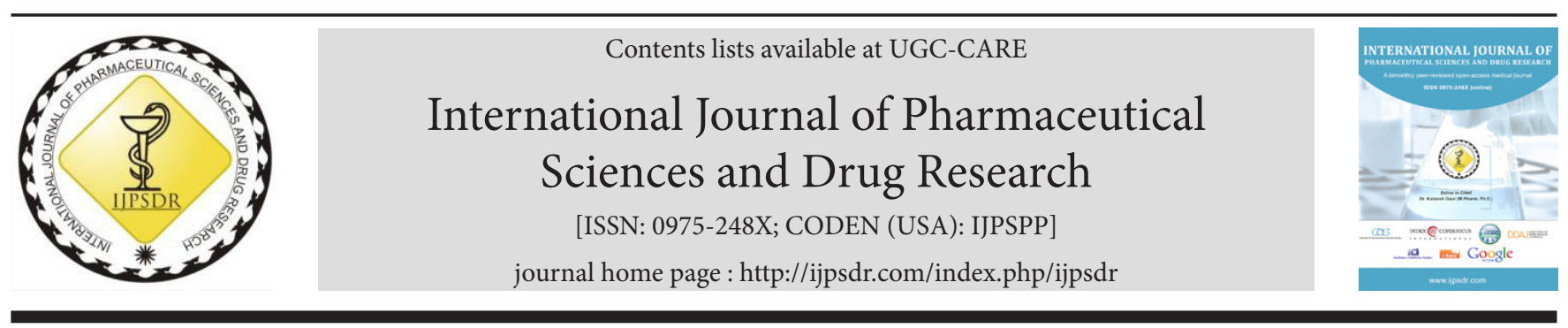

Research Article

\title{
Production of Value Added Oyster Mushrooms
}

\author{
Bandhakavi Sailaja, Batchu Radhika* \\ Institute of Pharmaceutical Technology, Sri Padmavati Mahila Visvavidyalayam, Tirupati-517502, Andhra Pradesh, India
}

\author{
A R T I C L E IN F O \\ Article history: \\ Received: 16 August, 2020 \\ Revised: 17 October, 2020 \\ Accepted: 29 October, 2020 \\ Published: 30 November, 2020 \\ Keywords: \\ Butea monosperma, \\ Cinnamaldehyde, \\ Cinnamonom zeylianica, \\ Flavonoids, \\ Moringa olifera, \\ Mushrooms. \\ DOI: \\ 10.25004/IJPSDR.2020.120608
}

\begin{abstract}
A B S T R A C T
Mushrooms are ironic in nutrimental resources and have converted into one of the common foods in the previous twenty years globally. The types of edible mushrooms are button, milky and oyster mushrooms. The research aimed at the value addition of oyster mushrooms by rising on paddy substrate complemented with two concentrations of four different medicinal plants. The plant parts selected were flowers of Butea monosperma, leaves of Moringa olifera, bark of Cinnamonom zeylianicum, fruits of Corindraum sativum at 5 and $10 \%$ concentration. Different species of oyster mushrooms are available. In the present study, Pleurotus florida was selected for value addition. Maximum mycelium running rate was detected in Cinnamon bark (5\%) and paddy straw (95\%) accompanied group and lowermost running rate of mycelium was observed in moringa leaf (5\%) and paddy straw (95\%). The primordial arrival was fast with cinnamon bark (5\%) supplemented group and slowest in moringa leaf (5\%) supplemented group. The mushrooms grown-up on coriander fruit (5\%) produced more, but the growth was slow. Mushrooms supplemented with Butea flower (5\%) exhibited slow growth, and yield was next to coriander fruit supplemented mushrooms. The produced mushrooms were subjected to physical evaluation, preliminary phytochemical testing, and tested to estimate total flavonoids, total phenols, total tannins, and total cinnamaldehyde contents. The value addition of oyster mushrooms was successful with cinnamon bark as cinnamaldehyde was noticed in the cinnamon bark supplemented group and with Moringa leaves flavonoids was observed in more concentration in moringa leaf supplemented mushroom group.
\end{abstract}

\section{INTRODUCTION}

Mushrooms are ideal as a source of minerals, high amount of protein, vitamins, and essential amino acids. ${ }^{[1]}$ At present, mushroom cultivation has been an attractive commercial occupation as people are extensively consuming mushrooms in their diet for nutrients, taste and flavor. ${ }^{[2]}$ Mushrooms can be effortlessly cultivated, grown in a wide range of temperatures on paddy straw, wheat straw and sugarcane bagasse. The lignocellulose content of the paddy straw favors the growth of mushrooms. ${ }^{[3-6]}$ Plurotus genus has about $40-50$ species available among which more acquainted and generally used are P. florida, Pleurotus ostreatus (P. ostreatus) and Pleurotus sajor-caju (P. sajorcaju). ${ }^{[7-9]}$ This study was focused on P. florida, which is commonly known as "Oyster mushroom." The species can be grown easily and at a faster rate compared to button and milky mushrooms as it does not require casing for the growth of mushrooms which is the hardest part in the growth. Production of value-added mushrooms by adding medicinal plant parts to a substrate is the first of its kind globally. Development of oyster mushroom on cotton waste modified with maize and banana leaves was reported by Waqas Ahmad et al., 2011. ${ }^{[10,11]}$ Their results report that $100 \%$ cotton waste and $50 \%$ cotton waste $+50 \%$ banana leaves are appropriate for the farming of mushrooms as compared to other growth media. Our study is unique of its kind in incorporating medicinal plant extracts for the growth of mushrooms. The selected medicinal plant parts for value addition of mushrooms were flowers of Butea monosperma, leaves of $M$. olifera, bark of $C$. zeylianicum, and fruits of $C$. sativum; the selection was based on their chemical constituents and biological activities.

\footnotetext{
*Corresponding Author: Mrs. B. Radhika

Address: Institute of Pharmaceutical Technology, Sri Padmavati Mahila Visvavidyalayam, Tirupati-517502, Andhra Pradesh, India

Email $₫$ : radhiyre@gmail.com

Tel.: +91-9440557753

Relevant conflicts of interest/financial disclosures: The authors declare that the research was conducted in the absence of any commercial or financial relationships that could be construed as a potential conflict of interest.

Copyright (C) 2020 B. Sailaja et al. This is an open access article distributed under the terms of the Creative Commons Attribution- NonCommercialShareAlike 4.0 International License which allows others to remix, tweak, and build upon the work non-commercially, as long as the author is credited and the new creations are licensed under the identical terms.
} 


\section{MATERIAL AND METHODS}

\section{Collection of Plant Materials}

The present work was carried out in the lab of Vaageswari College of Pharmacy, in Karimnagar, Telangana, in the month of November 2019. The fresh spawn is procured from 'S' Mushroom Agritech from Kukatpally, Hyderabad.

\section{Method of Preparation}

Preparation of paddy straw substrate for bags and treatment of straw was done as described elsewhere. ${ }^{[12,13]}$ The present work deals growth of mushrooms on the paddy straw along with few medicinally active plant parts supplementary to the substrate to grow the valueadded mushrooms. The plant parts are B. monosperma flowers, $M$. olifera leaves, $C$. zeylianicum bark, $C$. sativum fruits in $5 \%$ and $10 \%$ concentrations. Then inoculation of the straw was done as described by Daniel J. ${ }^{[14]}$ The inoculated bags were kept in an incubation room that is neat, clean and cool for whitish mycelium growth appeared at $10-32^{\circ} \mathrm{C}$ but effectively grew at $22-25^{\circ} \mathrm{C}$. The relative humidity required for proper growth is $80 \%$ to $85 \%$, and it is maintained by the spraying of water twice a day. ${ }^{[15,16]}$ Mycelium running rate in spawn packet, time required for completion of mycelium running, time required for primordia initiation, time required for harvesting was recorded. Stalk length, stalk diameter, pileus diameter, pileus thickness, average individual weight of fruiting body, biological yield, economic yield was also noted. ${ }^{[16]}$

\section{Biological Yield (g)}

Biological yield is measured by taking the whole bunch of the mushroom without removing the lower hard and dirty portion. ${ }^{[17]}$

\section{Economic Yield}

Economic yield is known by taking the weight of the mushroom bunch by removing the lower hard and dirty portion. ${ }^{[17,18]}$

\section{Drying of Mushrooms}

The fully grown mushrooms are collected, and parameters are measured and then cut into small pieces, which help to dry the mushrooms faster and better. ${ }^{[18] \text {. }}$

\section{Moisture Content}

Generally mushroom contains an abundant amount of moisture, the moisture present in different mushrooms of the value-added substrate is calculated with the help of the hot air oven and the loss in weight of the fresh mushroom sample to the dry sample after 24 hours keeping in the oven and it is measured with the help of the formula $^{[19]}$

Moisture content = Initial Weight-Final weight/Initial Weight of sample $\times 100$

\section{Biological Efficiency}

The biological efficiency of oyster mushroom was determined by the following formula ${ }^{[20]}$

Biological efficiency $=$ Total weight of the fresh mushroom fruiting bodies (g)/Weight of dry substrate (g) X 100

\section{Extraction of Mushroom}

All the Freshly collected value-added mushrooms of 10 gms weight is taken, and it is made into paste with the solvent 95\% ethanol and keep for maceration for 1-week and the marc was filtered and the distillate is dried and used as the mushroom extract. ${ }^{[20-21]}$

\section{Identification Tests for the Mushroom Extracts}

Preliminary biochemical tests for different extracts is performed for the carbohydrates, proteins, steroids, glycosides, cardiac glycosides, flavonoids, alkaloids, tannins, phenols, saponins, terpenoids, volatile oils, resins and fixed oil was carried out on the ethanolic extract by using standard methods mentioned in standard books. ${ }^{[21-23]}$

\section{Extraction of Flavonoids from Crude Extract}

The Moringa substituted mushrooms (5\%) are extracted with alcohol to obtain the crude extract; the extract is further hydrolyzed to obtain the flavonoids. The hydrolysis method was used in this study. M. oleifera leaf substituted mushroom extracts $(50 \mathrm{mg})$ were refluxed at $80^{\circ} \mathrm{C}$ for 2 hours with $1.2 \mathrm{M}$ hydrochloric acid in $50 \%$ aqueous methanol ( $5 \mathrm{~mL}$ ). Antioxidant (ascorbic acid ASA) was added to the hydrolysis reaction (10 mg) before refluxing. After refluxing, sample was allowed to cool to room temperature and keep for drying. ${ }^{[2]}$ The obtained extract is further confirmed for the presence of flavonoids by identification test (Ammonia test, Shinoda test, Lead acetate test), TLC, UV analysis. ${ }^{[24]}$

\section{TLC of Flavonoids}

TLC plate was spotted with the extract obtained after the hydrolysis of ethanolic extract of Moringa substituted mushrooms, control mushroom extract, and standard quercetin. The solvent system used was Toluene: Ethyl acetate: Formic acid (6:4:1). The spots were detected under UV light.

\section{Estimation of Total Flavonoid Content ${ }^{[23-25]}$}

Different concentration of 25, 50, 75, 100, 125 and 150 $\mathrm{mcg} / \mathrm{mL}$ quercetin were prepared. To each of these $4 \mathrm{~mL}$ water was added, followed by $0.3 \mathrm{~mL}$ of $5 \%$ sodium nitrite. After $5 \mathrm{~min} 0.3 \mathrm{~mL}$ of $10 \%$ aluminum chloride solution and at the 6 th minute, $2 \mathrm{~mL}$ of $1 \mathrm{M}$ Sodium hydroxide was added. The total volume was made up to $10 \mathrm{~mL}$ with distilled water. A blank was prepared without the addition of aluminum chloride solution. The solutions were mixed well, and the absorbance was measured against the blank 
at $510 \mathrm{~nm}$ using UV spectrophotometer. A standard graph was plotted using various concentrations of quercetin and their corresponding absorbance.

The total Flavonoids content of moringa substituted mushroom extract was estimated by a method described by Zhishen et al. ${ }^{[25,26]}$

\section{Estimation of Total Phenolic Content ${ }^{[26-29]}$}

The total phenolic content of extracts was studied with Folin-Ciocalteu assay. $1 \mathrm{~mL}$ of mushroom extract $(1 \mathrm{mg} / \mathrm{mL})$ was mixed with 1 -mL of Folin-Ciocalteu's phenol reagent. Keep aside for 5 minutes. The above solution $10 \mathrm{~mL}$ of $7 \%$ sodium carbonate solution was added to the Folin-Ciocalteu's added mixture, followed by $13 \mathrm{~mL}$ of deionized distilled water and mixed thoroughly. The prepared mixture was kept in the dark for 90 minutes at $23^{\circ} \mathrm{C}$; after the completion of 90 minutes, the absorbance was measured at $760 \mathrm{~nm}$. The total phenolic content was determined from slope of the calibration curve, which was made by preparing a Gallic acid solution $(100,200,300$, $400,500 \mu \mathrm{g} / \mathrm{mL}$ ). The total Phenolic content was expressed as mg of Gallic acid equivalents (GAE)/g of dried sample.

\section{Estimation of Total Tannin Content ${ }^{[23,30]}$}

The Total Tannin Content was estimated by the FolinCiocalteu method. About $0.1 \mathrm{~mL}$ of the sample from $(1 \mathrm{mg} / \mathrm{mL})$ was added to a volumetric flask $(10 \mathrm{~mL})$ which was with $7.5 \mathrm{~mL}$ of distilled water and $0.5 \mathrm{~mL}$ of FolinCiocalteu phenol reagent, $1 \mathrm{~mL}$ of $35 \%$ sodium carbonate solution and made to $10 \mathrm{~mL}$ with distilled water. The mixture was mixed well and kept at room temperature for 30 minutes. Standard solutions of tannic acid $(100,200$, $300,400,500 \mu \mathrm{g} / \mathrm{mL}$ ) were prepared in the same manner as described earlier. Absorbance for extract samples and standard solutions were measured against the blank at $700 \mathrm{~nm}$ with a UV-visible spectrophotometer. The tannin content was expressed in terms of mg of tannic acid equivalents/g of dried sample.

\section{Extraction of Cinnamon Substituted Mushrooms}

All the Freshly collected Cinnamon substituted mushrooms of $10 \mathrm{gms}$ weight were taken, and it was made into a paste with the solvent $95 \%$ ethanol and kept for maceration about 1-week marc was filtered and the distillate was dried and used as the mushroom extract. ${ }^{[21]}$ The obtained extract is further confirmed for the presence of Volatile oils by identification test for cinnamaldehyde (Tollen's test and Ferric chloride test) and Eugenol (Ferric chloride test and Bayer's test) TLC, UV-visible spectroscopic analysis.

\section{Thin Layer Chromatography of Cinnamaldehyde}

Thin layer chromatography (TLC) plate was spotted with the ethanolic extract of Cinnamon substituted mushrooms, control mushroom extract and standard Cinnamaldehyde, we can observe the spot parallel to the standard spot that indicate it may contain Cinnamaldehyde. Solvent system used was Toluene: ethyl acetate in the ratio 93:7, detected under UV light.

\section{Preparation Curve Calibration of Cinnamaldehyde}

Cinnamaldehyde was weighed and dissolved in ethanol to obtain a stock standard $(1.0 \mathrm{mg} / \mathrm{mL})$. Cinnamaldehyde solutions were prepared in concentration $20-100 \mu \mathrm{g} / \mathrm{mL}$ for the calibration curve. The absorbance was measured at $287 \mathrm{~nm}^{[31]}$

\section{Preparation and Determination of Cinnamaldehyde from Extract}

The dried extract was prepared 1-mg/mL concentration with ethanol. The tube was stirred thoroughly for about 15 minutes. Then the obtained solution was filtered, and the filtrate solution was measured absorbance at the maximum wavelength of $290 \mathrm{~nm}$. Cinnamaldehyde levels were determined using a calibration curve. ${ }^{[32,33]}$

\section{RESULTS}

\section{Mycelium Running Rate}

Mycelium running rate (MRR) in spawn bag ranged from 0.4056-0.8757 cm/day (Table 1). The highest mycelium running rate was observed in Cinnamon bark pieces (5\%) + paddy straw $(95 \%)$.

Time required for primordia initiation, mushroom appearance, harvesting and for maturity and the results were represented in Table 2 .

\section{Dimensions of Fruiting Body (pileus and stripe)}

Length of pileus $(\mathrm{cm})$, thickness of pileus $(\mathrm{cm})$ and length of stripe (cm) of three randomly selected fruiting bodies was measured using a slide calipers and tabulated in the Table 3 and Fig. 1.

\section{Identification Tests for the Mushroom Extracts}

The value-added mushroom extracts are tested for identification tests for different phytochemical constituents, and the results are in Table 4.

Table 1: Days for spawn running

\begin{tabular}{lllll}
\hline Substrate & $25 \%$ & $50 \%$ & $75 \%$ & $100 \%$ \\
\hline B 1 & 5 & 8 & 10 & 15 \\
B 2 & 5 & 8 & 10 & 15 \\
M 1 & 6 & 9 & 12 & 17 \\
M 2 & 6 & 9 & 11 & 14 \\
CN 1 & 3 & 6 & 8 & 10 \\
CN 2 & 3 & 7 & 9 & 12 \\
CO 1 & 5 & 8 & 10 & 15 \\
CO 2 & 4 & 7 & 10 & 13 \\
C & 4 & 6 & 10 & 12 \\
\hline
\end{tabular}

B1- Butea monosperma 5\%; B2- Butea monosperma 10\%; M1Moringa olifera 5\%; M2- Moringa olifera 10\%; CN1- Cinnamonom zeylianicum 5\%; CN2- Cinnamonom zeylianicum 10\%; C01Coriandrum sativum 5\%; CO2-Coriandrum sativum 10\%; C- Control 
Production of Oyster mushrooms

Table 2: Days for appearance of pin heads and maturity

\begin{tabular}{|c|c|c|c|c|}
\hline Substrate & $\begin{array}{l}\text { Average number of days for } \\
\text { primordial appearance }\end{array}$ & $\begin{array}{l}\text { Average number of days for } \\
\text { mushroom appearance }\end{array}$ & $\begin{array}{l}\text { Average number of days for } \\
\text { primordial to harvesting }\end{array}$ & $\begin{array}{l}\text { Average number of } \\
\text { days for maturity }\end{array}$ \\
\hline B 1 & 17 & 19 & 22 & 3 \\
\hline B 2 & 16 & 17 & 20 & 3 \\
\hline M 1 & 18 & 20 & 23 & 3 \\
\hline M 2 & 15 & 16 & 19 & 3 \\
\hline CN 1 & 11 & 12 & 15 & 3 \\
\hline $\mathrm{CN} 2$ & 13 & 14 & 16 & 2 \\
\hline CO 1 & 16 & 17 & 19 & 2 \\
\hline $\mathrm{CO} 2$ & 14 & 15 & 18 & 3 \\
\hline $\mathrm{C}$ & 13 & 14 & 17 & 3 \\
\hline
\end{tabular}

Table 3: Effect of different substrates on some yield attributes of oyster mushroom

\begin{tabular}{|c|c|c|c|c|c|c|c|c|}
\hline Substrate & $\begin{array}{l}\text { Pilus length } \\
(\mathrm{cm})\end{array}$ & $\begin{array}{l}\text { Pilus thickness } \\
(\mathrm{cm})\end{array}$ & $\begin{array}{l}\text { Stalk length } \\
(\mathrm{cm})\end{array}$ & $\begin{array}{l}\text { Fresh weight/ } \\
\text { biological yield (gm) }\end{array}$ & $\begin{array}{l}\text { Economic } \\
\text { yield }(\mathrm{gm})\end{array}$ & $\begin{array}{l}\text { Dry weight } \\
(\mathrm{gm})\end{array}$ & $\begin{array}{l}\text { Moisture } \\
\text { content }\end{array}$ & $\begin{array}{l}\text { Biological } \\
\text { efficiency }\end{array}$ \\
\hline B 1 & 5 & 0.3 & 5.5 & 36 & 34.8 & 6 & 83.3 & 7.2 \\
\hline B 2 & 8.5 & 0.5 & 9.2 & 73 & 72.2 & 13 & 82.1 & 14.6 \\
\hline M 1 & 7.5 & 0.5 & 8 & 72 & 70.3 & 10 & 86.1 & 14.4 \\
\hline M 2 & 9 & 0.5 & 5 & 26 & 25.1 & 6 & 76.9 & 5.2 \\
\hline CN 1 & 15 & 0.5 & 15 & 38 & 37.5 & 10 & 73.6 & 7.6 \\
\hline CN 2 & 6.6 & 0.5 & 8.5 & 78 & 76.9 & 16 & 79.4 & 15.4 \\
\hline CO 1 & 10 & 0.5 & 7.5 & 72 & 71.3 & 11 & 84.7 & 14.4 \\
\hline $\mathrm{CO} 2$ & 8.2 & 0.5 & 7.5 & 84 & 82.8 & 21 & 75.0 & 16.8 \\
\hline $\mathrm{C}$ & 7.5 & 0.6 & 8.5 & 67.6 & 66.3 & 11 & 83.7 & 13.5 \\
\hline
\end{tabular}

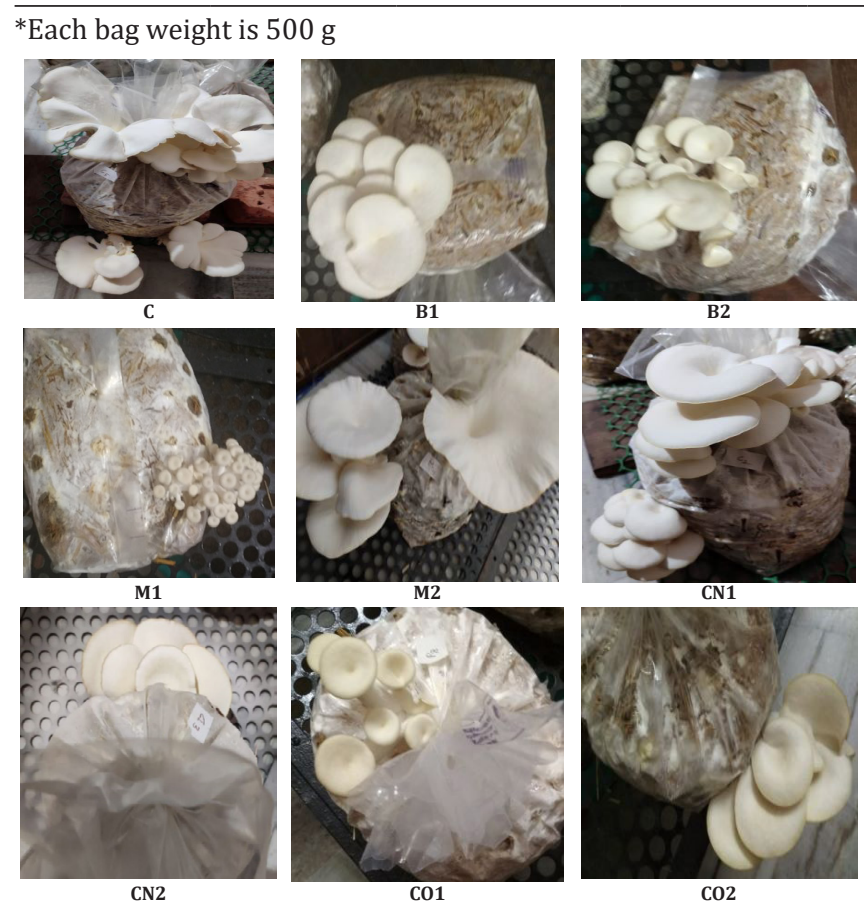

Fig.1: Effect of different substrates on Oyster mushroom

\section{Identification Tests of Flavonoids}

The value-added mushroom extracts are further hydrolyzed to get the flavonoids; the obtained extracts are tested for the presence of flavonoids and are represented in Table 5.
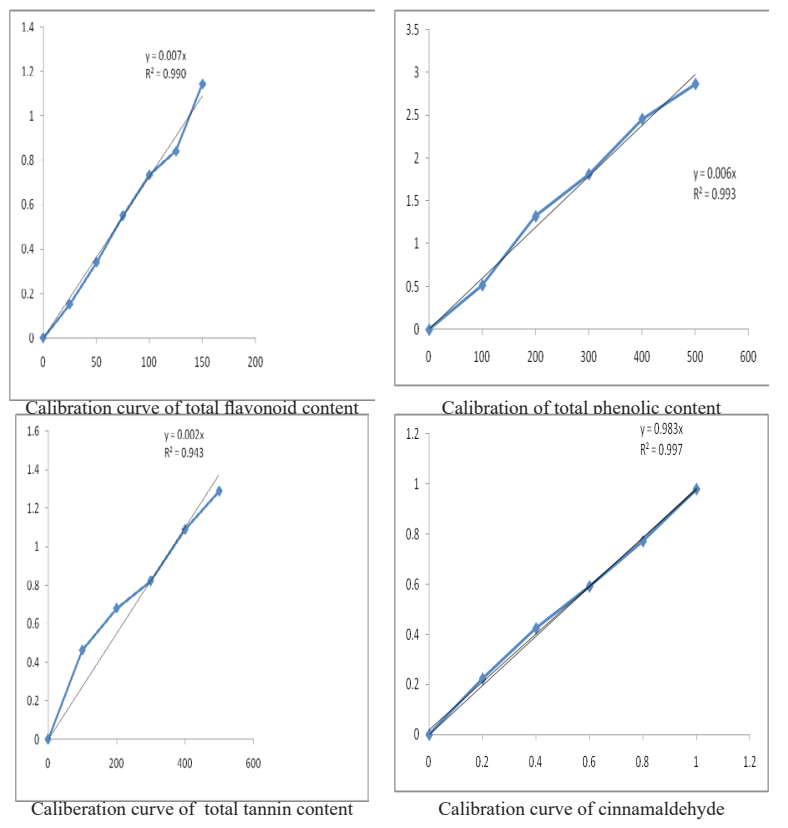

Fig.2: Calibration curve of total flavonoid content, total phenolic content, total tannin content and cinnamaldehyde.

\section{Estimation of Total Flavonoid Content}

The results of absorbance of the standard quercetin, standard gallic acid, standard tannic acid, Moringa substituted mushroom extract or cinnamon substituted 


\section{B. Sailaja et al.}

Table 4: Identification tests for the mushroom extracts

\begin{tabular}{|c|c|c|c|c|c|c|c|c|c|}
\hline Constituents & Butea $5 \%$ & Butea10\% & $\operatorname{Mor} 5 \%$ & Mor10\% & Cinn $5 \%$ & Cinn10\% & $\operatorname{Cor} 5 \%$ & $\operatorname{Cor} 10 \%$ & Con \\
\hline \multicolumn{10}{|l|}{ Carbohydrates } \\
\hline 1.Molisch test & + & + & + & + & + & + & + & + & + \\
\hline \multicolumn{10}{|l|}{ Proteins } \\
\hline 1.Biuret test & + & + & + & + & + & + & + & + & + \\
\hline 2.Xanthoprotien test & + & + & + & + & + & + & + & + & + \\
\hline 3.Test for 'S 'proteins & + & + & + & + & + & + & + & + & + \\
\hline \multicolumn{10}{|l|}{ Steroids } \\
\hline 1.Salkowski test & + & + & + & + & + & + & + & + & + \\
\hline 2.Liebermann-Buchard test & + & + & + & + & + & + & + & + & + \\
\hline \multicolumn{10}{|l|}{ Glycosides } \\
\hline 1.Keller Killiani test & + & + & + & + & + & + & + & + & + \\
\hline \multicolumn{10}{|l|}{ Flavanoids } \\
\hline 1.Shinoda test & + & + & ++ & ++ & + & + & + & + & + \\
\hline 2.sulphuric acid & + & + & ++ & ++ & + & + & + & + & + \\
\hline 3.NH3 test & + & + & ++ & ++ & + & + & + & + & + \\
\hline \multicolumn{10}{|l|}{ Alkaloids } \\
\hline 1.Dragendroff's test & ++ & ++ & + & + & + & + & + & + & + \\
\hline 2.Mayers test & ++ & ++ & + & + & + & + & + & + & + \\
\hline \multicolumn{10}{|c|}{ Tannins and Phenolic Compounds } \\
\hline $1.5 \% \mathrm{Fecl}_{3}$ & + & + & + & + & + & + & + & + & + \\
\hline 2.Lead acetate & + & + & + & + & + & + & + & + & + \\
\hline \multicolumn{10}{|l|}{ Saponins } \\
\hline 1.Foam test & - & - & - & - & - & - & - & - & - \\
\hline 2.Haemolytic test & - & - & - & - & - & - & - & - & - \\
\hline \multicolumn{10}{|l|}{ Volatile Oils } \\
\hline 1. $\mathrm{Fecl}_{3}$ test & + & + & + & + & ++ & ++ & ++ & ++ & + \\
\hline
\end{tabular}

Table 5: Identification tests of flavonoids

\begin{tabular}{lll}
\hline & $\begin{array}{l}\text { Moringa substituted mushroom } \\
\text { Test }\end{array}$ & \\
\hline Ammononia test & ++ & Control \\
Shinoda test & ++ & + \\
Lead acetate test & ++ & + \\
\hline
\end{tabular}

mushroom extract and Control was shown in the Table 6 and the standard curve was plotted which was shown in Fig. 2.

\section{TLC of Flavonoids}

The extracted and hydrolyzed moringa substituted mushroom extracts are subjected to TLC analysis which shows the presence of flavonoids compared to the standard quercetin. The results and TLC plate were shown in the Table 7 and Fig. 3.

\section{TLC of Cinnamaldehyde}

The ethanolic extract of cinnamon substituted mushroom extracts are subjected to TLC analysis, which shows the presence of cinnamaldehyde compared to the standard

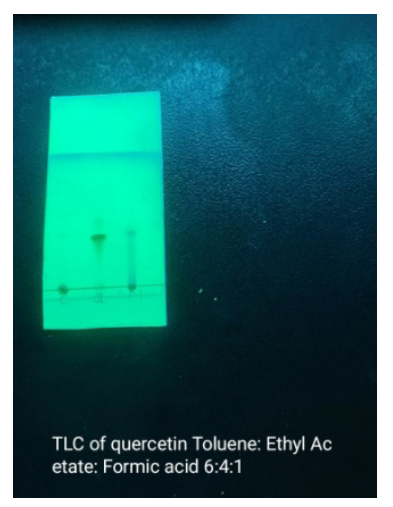

TLC of flavonoids

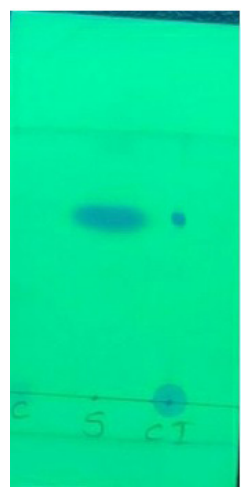

TLC of cinnamaldehyde

Fig.3: TLC of flavonoids and cinnamaldehyde

cinnamaldehyde. The results and TLC plate were shown in the Table 8.

The cinnamon bark substituted mushroom was extracted with ethanol and subjected to identification tests and the results are showed in the Table 9. 
Production of Oyster mushrooms

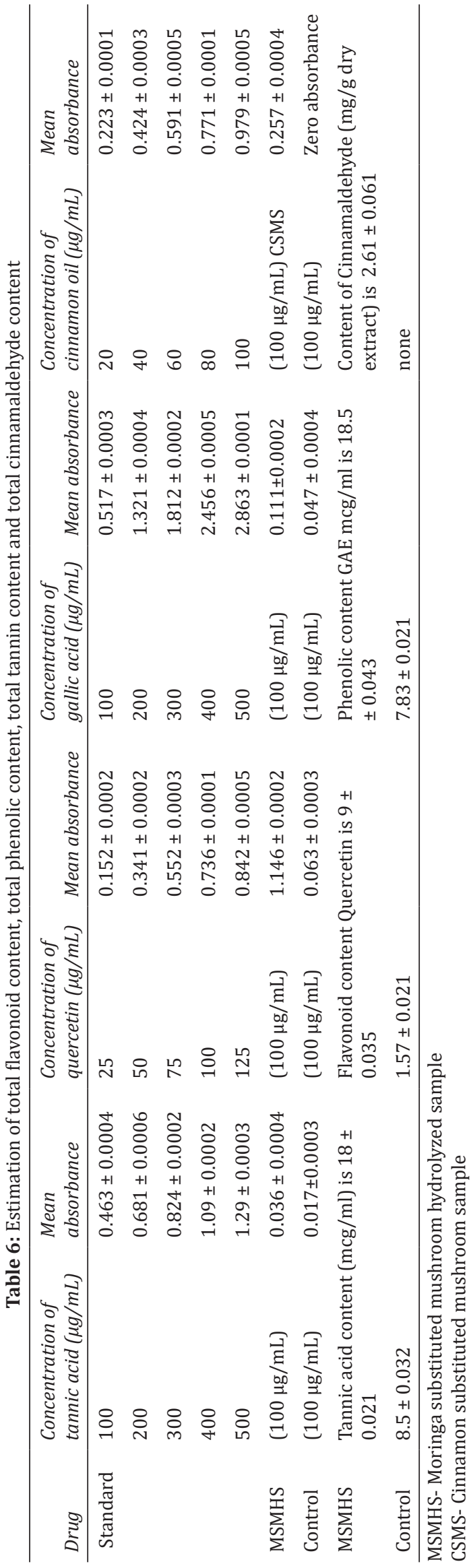

Table 7: TLC of flavonoids

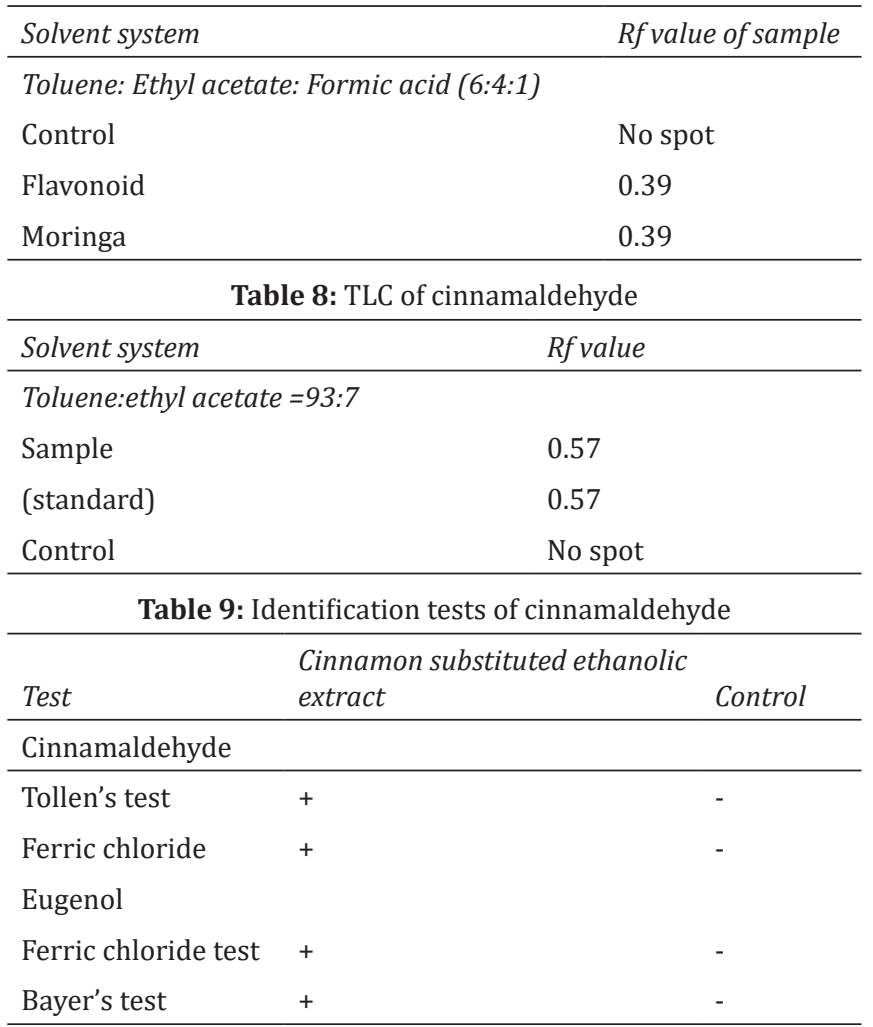

DISCUSSION

Mycelium running rate (MRR) in spawn bag ranged from $0.4056-0.8757 \mathrm{Cm} /$ day. The highest mycelium running rate was observed in Cinnamon bark pieces (5\%) + paddy straw (95\%). The lowest mycelium rate is recorded in Moringa leaves (5\%) + paddy straw (95\%), Because of the presence of cellulose present in the bark of cinnamon, which helps to grow faster. The lowest growth rate is Moringa is may be due to the presence of antifungal properties of the plant, but it has very good medicinal values. For better mycelium growth, the C: $\mathrm{N}$ ratio is responsible, which is good in the paddy straw. Average number of days for complete growth of mycelium in a packet is between 10 to 17 days, depending on the different compositions of the valueadded substrates. The least number of days for Cinnamon bark pieces (5\%) + paddy straw (95\%) and highest number of days for Moringa olifera leaf powder (5\%) + paddy straw (95\%). The difference in the mycelium growth in the bags is due to the variation in the chemical composition, $\mathrm{C}: \mathrm{N}$ ratio, and may be due to the value-added substances. ${ }^{[25]}$ Previously reported that spawn took 16 to 25 days after inoculation. ${ }^{[26,27]}$ But in the present work it is completed in 17days may be because of the cellulose present in the value added products.The least time for primordial appearance is in Cinnamon bark pieces (5\%)+ paddy straw (95\%), i.e., 11 days, which was followed by Cinnamon bark pieces $(10 \%)+$ paddy straw $(90 \%)$ and control (C), i.e., 13 days and the more time taken for primordial appearance is M. olifera leaf powder (5\%)+ paddy straw 
(95\%), i.e., 18 days. Previously it was reported that the primordial initiation took about 6 days after complete growth of mycelium, but with the value-added substrates, the primordial initiation is fast. ${ }^{[26-28]}$ The minimum time required for the mushroom appearance is observed in cinnamon bark pieces (5\%)+ paddy straw (95\%), i.e., in 12 days and more number of days taken for the mushroom appearance is $M$. olifera leaf powder (5\%) + paddy straw (95\%) i.e., 20 days. All the substrate bags are matured in almost in equal time, i.e., is 2 to 3 days may because the substrate is common in all the bags, i.e., rice straw. But the minimum time taken to get the mushrooms is in cinnamon bark pieces (5\%) + paddy straw (95\%), i.e., in 15 days, and the maximum time is for M. olifera leaf powder $(5 \%)+$ paddy straw (95\%), i.e., 23 days ${ }^{[29]}$. Mushrooms grown on cinnamon bark supplemented substrate showed the presence of cinnamaldehyde on TLC, identification, and Total cinnamaldehyde content. On preliminary phytochemical screening, mushrooms grown on four substrates and control group, when compared with the control group exhibited more concentrations of flavonoids, phenolic compounds, tannins, glycosides. In mushrooms grown with butea supplemented substrate shows more concentrations of alkaloids and equal concentration of flavonoids. Mushrooms grown on moringa showed more concentration of total flavonoids when compared to the control group. Flavonoid was also observed in the Moringa treated group, which was absent in the TLC control group and in quantitative estimation by UV-visible spectroscopy. Cinnamon substituted mushrooms show the presence of cinnamaldehyde and eugenol by identification tests, which are not found in control group. Coriander fruits substituted mushrooms show an equal amount of volatile oil compared to control. Flavonoids in moringa was observed by TLC, identification tests, total flavonoid content, total tannin content and total phenolic content. The presence of cinnamaldehyde in cinnamon substituted mushrooms was studied by identification tests, TLC, estimation of cinnamaldehyde content by UV-visible spectrophotometer.

\section{CONCLUSiON}

Flowers of Butea monosperma, leaves of M. olifera, bark of $C$. zeylianicum, fruits of $C$. sativum at 5 and $10 \%$ concentrations were found to be the best one for the growth and yield of Pleurotus florida. These medicinal plants with the potent amounts of flavonoids, phenols, cinnamaldehyde and tannins are responsible for the growth of mushrooms. These plants are cost-bearing and poor farmers will be able to use them for the production of mushroom. They are easily available locally and can be used for the preparation of mushroom substrate as well. In this way, the selected phytochemicals will be fruitful to reduce the cost of production of mushrooms for ordinary mushroom growers.

\section{REFERENCES}

1. Mueller M, Cantner EW. Mushroom cultivation for feed and food. Entwicklung-und-laendlicher-Raum (Germany, FR). 1990;22(2): 15-17.

2. Shah ZA, Ashraf M, Ishtiaq M. Comparative study on cultivation and yield performance of oyster mushroom (Pleurotus ostreatus) on different substrates (wheat straw, leaves, saw dust). Pakistan Journal of Nutrition. 2004;3(3):158-160.

3. Khanna P, Garcha HS. Pleurotus mushroom-A source of food protein. Mushroom news lett tropics. 1984;4:9-14.

4. Maftoun P, Johari H, Soltani M, Malik R, Othman NZ, El Enshasy HA. The edible mushroom Pleurotus spp.: I. Biodiversity and nutritional values. International Journal of Biotechnology for Wellness Industries. 2015 Jul 27;4(2):67-83.

5. Musieba F, Okoth S, Mibey RK. First record of the occurrence of Pleurotus citrinopileatus Singer on new hosts in Kenya.

6. Gargano ML, Zervakis GI, Venturella G, editors. Pleurotus nebrodensis A Very Special Mushroom. Bentham Science Publishers; 2013 Nov 18.

7. Pramanik M, Chakraborty I, Mondal S, Islam SS. Structural analysis of a water-soluble glucan (Fr. I) of an edible mushroom, Pleurotus sajor-caju. Carbohydrate Research. 2007 Dec 10;342(17):26702675.

8. Dey B, Bhunia SK, Maity KK, Patra S, Mandal S, MaitiS, Maiti TK, Sikdar SR, Islam SS. Chemical analysis of an immunoenhancing watersoluble polysaccharide of an edible mushroom, Pleurotus florida blue variant. Carbohydrate Research. 2010 Dec 10;345(18):27362741.

9. Rout D, Mondal S, Chakraborty I, Pramanik M, Islam SS. Chemical analysis of a new $(1 \rightarrow 3)-,(1 \rightarrow 6)$-branched glucans from an edible mushroom, Pleurotus florida. Carbohydrate Research. 2005 Nov 21;340(16):2533-2539.

10. Maftoun P, Johari H, Soltani M, Malik R, Othman NZ, El Enshasy HA. The edible mushroom Pleurotus spp.: I. Biodiversity and nutritional values. International Journal of Biotechnology for Wellness Industries. 2015 Jul 27;4(2):67-83.

11. Mandeel QA, Al-Laith AA, Mohamed SA. Cultivation of oyster mushrooms (Pleurotus spp.) on various lignocellulosic wastes. World Journal of Microbiology and Biotechnology. 2005 Jun 1;21(4):601-607.

12. Krishnamoorthy AS. Commercial prospects of milky mushroom (Calocybe indica) in the tropical plains of India. Current vistas in mushroom biology and production. Solan (HP): Mushroom Society of India. 2003:131-135.

13. Zhang R, Li X, Fadel JG. Oyster mushroom cultivation with rice and wheat straw. Bioresource technology. 2002 May 1;82(3):277-84.

14. Savoie JM. Biological resources and breeding for improvements in the production of the button mushroom in small-scale farming. Bulletin of the World Society for Mushroom Biology and Mushroom Products. 2013; 8:1-7.

15. Gomez KA, Gomez AA. Statistical procedures for agricultural research. John Wiley \& Sons; 1984 Feb 17.

16. Mondal SR, Rehana J, Noman MS, Adhikary SK. Comparative study on growth and yield performance of oyster mushroom (Pleurotus florida) on different substrates. Journal of the Bangladesh Agricultural University. 2010;8(2):213-220.

17. Bhattacharjya DK, Paul RK, Miah MN, Ahmed KU. Effect of different saw dust substrates on the growth and yield of oyster mushroom (Pleurotus ostreatus). IOSR Journal of Agriculture and Veterinary Science. 2014; 7:38-46. Trease ge, evans wc pharmacognosy xii ed london, bailere london 1994 .

18. Sarker NC, Hossain MM, Sultana N, Mian IH, Karim AJ, Amin SR. Performance of different substrates on the growth and yield of Pleurotus ostreatus (Jacquin ex Fr.) Kummer. Bangladesh J. Mushroom. 2007;1(2):9-20.

19. Raghuramulu N, Nair KM, Kalyanasundaram S, editors. A manual of laboratory techniques. National Institute of Nutrition, Indian Council of Medical Research; 1983. 
20. Bano A, Dorffling K, Bettin D, Hahn H. Abscisic acid and cytokinins as possible root-to-shoot signals in xylem sap of rice plants in drying soil. Functional Plant Biology. 1993;20(1):109-115.

21. Jayakumar T, Thomas PA, Geraldine P. In-vitro antioxidant activities of an ethanolic extract of the oyster mushroom, Pleurotus ostreatus. Innovative Food Science \& Emerging Technologies. 2009 Apr 1;10(2):228-234.

22. Panya T, Chansri N, Sripanidkulchai B, Daodee S. Additional antioxidants on the determination of quercetin from Moringa oleifera leaves and variation content from different sources. International Food Research Journal. 2018;25(1):51-55.

23. Saeed N, Khan MR, Shabbir M. Antioxidant activity, total phenolic and total flavonoid contents of whole plant extracts Torilis leptophylla L. BMC complementary and alternative medicine. 2012 Dec 1;12(1):221.

24. Aliyu AB, Ibrahim MA, Musa AM, Musa AO, Kiplimo JJ, Oyewale AO. Free radical scavenging and total antioxidant capacity of root extracts of Anchomanes difformis Engl. (Araceae). Acta Pol Pharm. 2013 Jan 1;70(1):115-121.

25. Riaz T, Abbasi AM, Shahzadi T, Ajaib M, Khan MK. Phytochemical screening, free radical scavenging, antioxidant activity and phenolic content of Dodonaea viscosa. Journal of the Serbian Chemical Society. 2012;77(4):423-435.

26. Khadabadi SS, Deore SL, Baviskar BA. Experimental phytopharmacognosy. Nirali prakashan, page. 2011 May (47).
27. Vijay D Tambe, Rajendra S Bhambar. Estimation of Total Phenol, Tannin, Alkaloid and Flavanoid in Hibiscus Tiliaceus Linn. Wood Extracts. Journal of Pharmacognosy and Phytochemistry. 2014; 2(4):41-47.

28. Singh R, Verma PK, Singh G. Total phenolic, flavonoids and tannin contents in different extracts of Artemisia absinthium. Journal of Complementary Medicine Research. 2012;1(2):101-104.

29. Alhakmani F, Kumar S, Khan SA. Estimation of total phenolic content, in-vitro antioxidant and anti-inflammatory activity of flowers of Moringa oleifera. Asian Pacific journal of tropical biomedicine. 2013 Aug;3(8):623.

30.Govindappa M, Poojashri MN, Santoyo G, Sharanappa P. Antimicrobial, antioxidant and in vitro anti-inflammatory activity and phytochemical screening of water extract of Wedelia trilobata (L.) Hitchc. Journal of medicinal plants research. 2011 Oct 30;5(24):5718-5729.

31. Truong VT. Effect of cinnamic acid-cyclodextrin inclusion complexes on populations of Escherichia coli 0157: H7 and Salmonella enterica in fruit juices (Doctoral dissertation, Virginia Tech).

32. Clark GS. An Aroma Chemical Profile, Cinnamic Aldehyde. Commodity Services International Inc. Maryland. 1991:25-30.

33. Wardatun S, Rustiani E, Alfiani N, Rissani D. Study effect type of extraction method and type of solvent to cinnamaldehyde and transcinnamic acid dry extract cinnamon (Cinnamomum burmanii [Nees \& T, Nees] Blume). Journal of Young Pharmacists. 2017;9(1):S49.

HOW TO CITE THIS ARTICLE: Sailaja B, Radhika B. Production of value added oyster mushrooms. Int. J. Pharm. Sci. Drug Res. 2020;12(6):652-659. DOI: $10.25004 /$ IJPSDR.2020.120608 